\title{
Position of Commercial Arbitration in Resolving Disputes among Customers and Banks in Iran
}

\author{
Saeid Eshragh Abad Shahpori ${ }^{1} \&$ Zeynab Porkhaghan Shahrezaei ${ }^{2}$ \\ ${ }^{1}$ Private Law, Islamic Azad University, Isfahan( Khorasgan) Branch, Isfahan, Iran \\ ${ }^{2}$ Assistant Professor, Islamic Azad University, Isfahan (Khorasgan) Branch, Isfahan, Iran \\ Correspondence: Zeynab Porkhaghan Shahrezaei, Assistant Professor, Islamic Azad University,Isfahan \\ (Khorasgan) Branch, Isfahan, Iran. E-mail: zeynab.porkhaghanshahrezaei@chmail.ir
}

\author{
Received: December 30, $2016 \quad$ Accepted: January 24, $2017 \quad$ Online Published: June 1, 2017 \\ doi:10.5539/jpl.v10n3p174 \\ URL: https://doi.org/10.5539/jpl.v10n3p174
}

\begin{abstract}
In today's business environment and financial markets, banks are responsible for financial intermediaries and their relationships with customers are established in form of signed contracts. We are witnessing disputes in monetary transactions; thus, parties tend to resolve their conflicts outside the framework of court due to continue cooperation in the future and preserve the value of money and the principle of confidentiality. This research has been conducted to determine the position of commercial arbitration in resolving disputes among banks and customers. Research method is descriptive-analytical and its practical aspects can be used in the banking system. Data has been gathered from theoretical library discussions, the ideas of legal experts, the principles finance and banking sciences, and banking conventions. The results indicate that banks do not like to refer files to arbitration and monetary market has no arbitration committee to resolve disputes. Therefore, banks have used alternative methods such as negotiation and referral to banking expert; in some cases, the role of expert is close to arbitrator. In other cases, resolving the dispute does not arbitration with respect to social order and legislation. Based on findings, main banking services are provided in the form of a contract written by banks in the framework of the Article 10 of the civil law. This contract contains terms. Customers have to accept the terms and sign the contract; otherwise, banks will not provide the considered services.
\end{abstract}

Keywords: bank, electronic banking, granted facilities, commercial arbitration, deposit receiving, customer

\section{Introduction}

Position of commercial arbitration in resolving disputes among banks and customers is one of the significant issues that require study and research. In economic cycle, banks are intermediaries between monetary and fiscal economic elements and banks, an economic institute, seek for success and customer orientation activities. They try to increase monetary and financial transactions. Bank is a non-public institution that presents banking services in order to make a profit with its capital and customer deposits as well as collecting deposits and granting loans and credits (Mosavian, 2014, p. 591). In this regard, the services of banks can be divided into four groups including deposit receiving customers, granted facilities, electronic banking, and supporting companies of private sector. Banks sign many various contracts to between themselves and different individuals to do monetary transactions and operations. Interaction and economic dependence on contracts and obligations arising from them will lead to identifying the concept of group contract in law; it reflects the attention of law to economic and commercial realities along with the legal structure of contract (Bahmani \& Moradi, 2015). In this contractual relationship between banks and customers, money plays a major role and time value of money is very important. In fact, this monetary interactions lead to emergence of financial disputes, they are mostly result from intentional or unintentional misunderstanding of brought funds, investment, or performance resulting from economic relations. These claims are arising from disagreement or complexity of accounts. However, compensating for the devaluation is an economic and legal issue. Moreover, parties prefer to refer the case to arbitration in this situation. Since commerce has a close relation to arbitration in the present situation of the world, many merchants and businesses prefer to resolve their conflicts on law and legal commitments by one or more of judge's judgment instead of court (Shiravi, 2013, p. 370). Arbitration rules enacted in Iran in the form of articles of the Civil Procedure Code and Law on International Commercial Arbitration in 2000. In the provisions relating to arbitration, Code of Civil Procedure emphasizes mostly on civil disputes and conflicts; hence, social 
and economic developments in addition to commercial and organizational arbitration have not been considered and explained enough (Mujtahedi, 2012).

Commercial arbitration refers to arbitration of disputes arising out of a commercial relationship or concerned with a business relationship. According to Article 2 of the Commercial Law, any kind of money exchange and banking operations is considered as a commercial operation. According to Article 3 of the same law, all business transactions and all transactions between businesspersons and shopkeepers and traders and banks are considered commercial operations due to business activities of traders or one of them. Thus, all banking transactions including private banks in the form of public companies and public banks in which the government is the main shareholder and act in the form of public company and are considered from government outsourcing with other businessmen are subject to commercial arbitration and can solve disputes in the form of commercial arbitration. This study first presents definitions and terms related to bank and customer; then, it addresses arbitration and its different types. This study explains limitations of arbitration in different aspects. Moreover, this study presents legal nature of banking operations and processes in relation to deposit receiving, loans, electronic banking and outsourcing to private companies to address arbitration in these processes.

\section{Definition of Customer and Bank}

\subsection{Customer}

Customer is the person who defines his need himself, consumes produced goods and services, and he is ready to pay a good cost for them. He accepts to pay the costs when he sees a value in the delivered goods and services that justifies the expenditure (Muhammadi, 2009, p. 45).

\subsection{Bank}

Bank is an institute having been found as a corporation in accordance with commercial law based on articles stipulated in monetary and banking law of the country and works by banking operations (Jafari Langroodi, 1991, p. 104). According to the law for Free Usury Banking, it is a non-governmental institute presenting banking services in order to make a profit with its capital and customer deposits as well as collecting deposits and granting loans and credits (Mosavian, 2014). According to various missions, banks are divided into four categories including commercial banks, development banks, specialized banks, and credit unions. In terms of the way of their shareholders, they are divided into four groups of governmental banks, private banks, semi-government banks, and credit institutions.

\section{Commercial Arbitration}

\subsection{Definition of Arbitration}

Arbitration literally means to refer a complaint to a judge; the judge's action is called arbitration. Arbitration is hostilities by non-judge without due process of formal proceedings (Jafari Langroodi, 1991). Arbitration can be regarded as a process through which parties resolve their conflicts on law and legal commitments by one or more of judge's judgment instead of court (Shiravi, 2013).

\subsection{Arbitration Types}

Arbitration can be classified with respect to subjects, institutions, and external elements. In terms of subject of referral to arbitration, it is divided to commercial and non-commercial; considering foundation, it is categorized to institutional arbitration and case arbitration. With regard to involvement of external elements, it is classified to domestic and international arbitrations (Pasha Bonyad, 2014, p. 34). Besides, arbitration can be divided considering parties' agreement to contractual arbitration and mandatory arbitration.

Non-commercial arbitration: According to Article five of the Commercial Code, all transactions by merchants are commercial unless it is proved that the trade is not related to commercial affairs. This law excludes real estate transactions from the domain of commercial ones. Based on Article 13 of Trade Act, transactions related to the personal needs of merchants are not commercial.

Commercial arbitration: With regard to the articles one to three of the Commercial Code, which is the document for lawyers in description of merchants and their commercial activities, commercial arbitration is one that tires to resolve claims rising from business behavior and business practices (Pasha Bonyad, 2014, p. 35).

With respect to the nationality of the parties, commercial arbitration is divided into two categories of domestic and international arbitrations.

International commercial arbitration: According to Note B of Article 1 of Law on International Commercial Arbitration, international arbitration occurs when a party is not a citizen of Iran at the time of concluding the 
arbitration agreement.

Domestic commercial arbitration: It is resolving disputes and conflicts on commercial relations and transactions among legal entities and natural persons as they are citizens of Iran at the time of making the arbitration agreement (Karimi \& Partou, 2013, p. 49).

Mandatory arbitration: a type of arbitration that the referral of dispute and claims to a person on whom both parties are agreed as an arbitrator (Jafari Langroodi, 1991, p. 284). This type of arbitration may be practiced in contractual form or the arbitrator is qualified without any agreement in advance.

Mandatory contractual arbitration: Although mandatory arbitration agreement has a contractual aspect that signed by parties, it seems that adjoining nature of the contract signifies lack of freedom and rejecting arbitration contracts would lead to non-conclusion of the contract (Karimi \& Partou, 2013, p. 58).

Mandatory non-contractual arbitration: in this type of arbitration, parties' disagreement is referred to arbitration without the presence of a contract; it is also called legal arbitration (Karimi \& Partou, 2013, p. 58).

Arbitration on consent: in consensual arbitration, parties refer the case to arbitration before or after the dispute (Jafari Langroodi, 1991, p. 284). This type of arbitration is also called contractual arbitration. Case arbitration: case arbitration describes a situation in which parties like to resolve the disputes among themselves without referral to a court; it is finished after issuance of a sentence by arbitrator (Pasha Bonyad, 2014). There is more freedom of action in this type of arbitration; arbitration principles are changeable by an agreement between parties.

Organizational arbitration: the authority to solve the case in this type of arbitration is an institution presenting arbitration services; arbitrators are determined by the tribunal authority, not the parties. Law governs this type of arbitration (Karimi \& Partou, 2013, p. 55).

\subsection{Arbitration Clause}

As mentioned, the foundation for arbitration is contract. If parties agree to refer the future disagreements to arbitrator in a separate contract, it is called arbitration clause. It is employed when the disagreement has not been emerged; the disagreement may never be occurred (Dashti \& Karimi, 2013, p. 101). In this manner, a contract should be concluded between parties in advance to authorize the arbitrator. In relation to the arbitration clause that has been inserted in the original contract, some believe that the arbitration clause contained in it will be canceled in the case of revoking or cancelling the contract because the arbitrators' competency to address the disputes relies on the arbitration clause; accordingly, arbitrators do not have jurisdiction to invalidity or termination of the contract (Shiravi, 2013). Nowadays, inclusion of an arbitration clause to resolve future disputes indicates real intention of the parties and the fact that they would like to keep close relationships despite acute disputes.

\subsection{Commercial Arbitration}

According to article two and three of Commercial Code, business transactions can be divided into two groups of main and consequential commercial transactions. According Article 2, the main commercial transactions include banking and insurance. Based on Article 3, operations are recognized as commercial in so far as one or both of the contracting parties are merchants, when all business transactions between merchants, tradesmen, money-exchangers and banks, when all business transactions between a merchant and a non-merchant for his commercial requirements, when all business transactions undertaken by the staff, employees or apprentices of merchants on behalf of their employers, and when all transactions of commercial companies (Hasani, 2012, p. 270). The Law Concerning International Commercial Arbitration covers only commercial arbitration as it argues in paragraph one of Article 2 that Arbitration of disputes in international commercial relations including purchase and sale of goods and services, transportation, insurance, financial matters, consulting services, investment, technical cooperation, representation, commission agency, contract work and other similar activities shall be carried out in accordance with the provisions of this Law. In this definition, there is no sign of any reference to Articles 2 and 3 of Commercial Code; it talks generally about any commercial activity (Shiravi, 2013, p. 33).

\section{Conditions and Limitations of Arbitration}

In the contracts concluded between the parties on economic and trade issues, the process of resolving future disagreements should be determined in the contract; it is included in the contract in form of arbitration clause or arbitration agreement in case of referral to arbitration. Agreement on referring to arbitration is concluded before dispute or after it. In additional contracts, referring to arbitration may be regarded mandatory due to imposition of arbitration clause; the coercion may directly result from legal articles and it is not related to the intention of 
parties including Article 53 of the General Agreement Terms that is about treaties on construction and public utilities; in the case of a dispute, parties refer to Technical Supreme Council (Karimi \& Partou, 2014). This mandatory arbitration is accepted by the other party and the contract is not concluded in the case of rejecting the arbitration. In forward sale contract, at least some items should be mentioned including introduction of the arbitrators who are going to solve disputes arising from the interpretation and enforcement of the contract (Sarvari, 2011). The important point in arbitration clause is the inclusion of conditions in the main contract. Therefore, arbitration clause will be canceled in the case of revoking or cancelling the contract because the arbitrators' competency to address the disputes relies on the arbitration clause; accordingly, arbitrators do not have jurisdiction to invalidity or termination of the contract (Shiravi, 2013). Article 16 of the Law Concerning International Commercial Arbitration stipulates that an arbiter may decide about his own competence and about the existence and/or validity of the arbitration agreement. An arbitration clause being part of a contract shall be considered an independent agreement for the purposes of this Law. The decision of the "arbitrator" concerning cancellation and annulment of such agreement, in itself, may not be construed as the annulment of the arbitration provided under a contract. Nevertheless, Article 461 of Civil Procedure Code does not allow the arbitrator to make such a decision. The question rising in this regard is whether arbitration clause is valid in a revocable contract or not? In response, it can be stated if performance of an action is conditioned for one of the parties in a revocable contract, the other party can request the court to force him. Defendant can remove the commitment and obligation by revoking the main contract but he is obliged to perform the action before revoking the contract. In addition, apparently, the presence of a clause in a revocable contract indicates the adherence of clause provisions to the contract; hence, the clause is revoked by termination of the contract. it is noteworthy to mention that the situation in which the clause is practiced indicates that the clause conditions are indeed independent and original contract. Therefore, the common wills of the parties can establish a commitment without the need to certain frameworks and formality based on Article 10 of the Civil Code (Katouzian, 2013, p. 578). Then, inserting arbitration clause is accepted. Besides, if the former contract is canceled due to lack of parties' competency arbitration clause is canceled, too. In this way, he cannot be a subject of Article 16 of Law on International Commercial Arbitration because the condition for referring a case to arbitration is a subsequential condition to the main contract and its observance is necessary only when the main contract is valid and effective. Accordingly, the disputes about the correctness of a contract cannot be referred to arbitration (Katouzian, 2013). In some cases, arbitration has a contractual base and it has been signed by the parties. Since the arbitration clause is additional in this type, there is no way to refuse signing the clause because its rejection leads to the termination of the contract. This trend is observed in the contracts concluded between state or organizations and private parties such as the contracts between government agencies and private contractors (Karimi \& partou, 2013). In this situation, arbitration clause is the requirement of the rule of law or the customs of contract. Terms of contract is connected undoubtedly to its provisions either they are stipulated explicitly, implicitly, or from the nature of contract and its customs. Contractual terms are the tools to express and uncover will or to complete and adjust contracts. Moreover, correlativity between the contract and conditions results from law and there is no need for inference of provisions from common will. Hence, legal materials should be considered as contract supplementary, not as its interpretation. Correlativity between implied terms and the contract arising from the customary is sometimes due to contractual customs and conventions. It means that content of a clause is repeated in a contract and prevails so that it is regarded as an instrument for transaction. The same as law, the conventional trend in this regard is an instrument to complete the contract; it may complete both sides. Therefore, one should accept that a real contractual term governs on it (Katouzian, 2013). Accordingly, the mentioned arbitration clause in the above contracts is not resulted from a common will; but the person signs them with his own intention and he accepts the arbitration clause.

\subsection{Arbitration of Public Claims}

One of the limitations of legislator in arbitration relates to differences in public claims. The subject of a public claim is public and state property. Based on Article 457 of Civil Procedure Code, referring claims on public and state property to arbitration should be performed after approval by Committee of Ministers and informing the Parliament. According a viewpoint, both parties of a dispute should be private entities. Thus, the sentence in Article 475 of the Code and Article 139 of the Constitution prevents the referral of disputes about public and property to arbitration. There is another idea proposing the state absolute immunity. It argues that governments are immune of investigation by any judicial authority that is outside the scope of their authority. They are immune of any type of dispute. Proponents of the theory of relative immunity of government believe that a state is immune only with respect to the property having been provided for it due to its sovereignty. Accordingly, the principle of state immunity has been been disregarded with respect to domestic laws as a justification to prevent possible preventions in Article 139 of the Constitution and Article 457 of Civil Procedure Code. It pays more 
attention to the ideas about accepting arbitration in disputes (Karimi \& partou, 2012).

\subsection{Arbitration of Disputes in Labor Rights}

There are many contracts between employees and employers in business space due to the employment; some disputes may rise in this situation. One choice to solve the problem is referral of the cases to arbitration. In this regard, the relationship between employee and employer, which is based on mutual agreement of wills, is a subject of supportive state regulations; they are mostly in favor of employees. The authority for solving disputes has been determined in the law of Iran. The rule is imperative and concluding a contract in its contradiction is not allowed (Pasha Bonyad, 2014).

\subsection{Arbitration of Insolvency Claims}

As noted, people can refer to arbitration only when they have been allowed to transfer freely the property that is subject of dispute. As the company should be abolished and clear its accounts at the time of insolvency, the company clear all its accounts and its abolishment does not allow the partners to occupy its shares. Since the company assets are warranty for the liabilities, it is not allowed to transfer it freely. The dispute in this regard is not referable to arbitration (Eskini, 2009, p. 298). In this manner, the legislator, according to Article 496 of Civil Procedure Code, has not allowed the referral of claims about insolvency to arbitration. Prohibition of arbitration in bankruptcy can be justified by its close relationship to the rights of third persons. Arbitration agreement is only effective for its parties while according to Articles 670 and 671 of Islamic Penal Code, the effect of bankruptcy claim in terms of third parties including other creditors is performed in the economy of the country. Thus, the prohibition on referring bankruptcy claims to arbitrations seems reasonable (Pasha Bonyad, 2014).

\subsection{Arbitration of Criminal Matters}

In the legal system of Iran, Only disputes with private nature can be referred to arbitration. According to Article 478 of Civil Procedure Code, if investigation of a case leads to discovery of an evidence about a crime (while it is effective in arbitration and separation of arbitration and criminal matter is impossible), solving the dispute is suspended to investigation of the crime; and arbitratin is stopped to the time of issuing a sentence about the crime by a competent court. The claim of adulteration in the document without determination of its agent is not a subject of this law (Karimi \& Partou, 2014).

\subsection{Arbitration against Law and Public Order}

Public order is associated with the the expediency of society. Government follows some specific patterns in its duties and it observes a specific order. Establishment of public order depends on the observance of all members. In public order or economy, state tries to lead economy and it supervises private contracts as a tool for distribution of wealth. It imposes the effects of such contracts on both parties as a crucial affair; hence, it limits the freedom in making contracts or in preventing to perform it. In this ragard and according to Article 34 of Law on International Commercial Arbitration, in case the content of the judgment is incompatible with public order or good neighborliness of the country and/or the imperative regulations of this law, arbitrator's award shall be nullified and inexecutable. In addition, according to Article 975 of Civil Code, the court cannot enforce foreign laws or private agreements which are contrary to public morals or which may be considered by virtue of injuring the feelings of society or for other reasons, as contrary to public order, notwithstanding the fact that the enforcement of such laws is permissible in principle. Although this rule addresses judicial investigations, it is effective for arbitrators' behavior (Pasha Bonyad, 2014).

\subsection{Arbitration of Immovable Property}

According to Article 34 of Law on International Commercial Arbitration, Arbitrator's award shall be nullified and in executable in case the arbitrator's award concerning immovable properties located in Iran is in contradiction with imperative regulations of the Islamic Republic of Iran and/or with the provisions of valid documents, unless the "arbitrator" has the right of compromise in the case of the latter. In addition, Civil Procedure Code is silent on arbitration prohibition on immovable property when it is discussed arbitration. It is silent because a large number of raised disputes in the courts are about immovable estate. Referring arbitration to immovable property have reduces the number of disputes in the courts (Pasha Bonyad, 2014). If the dispute solves in form of conciliation, mediation, or arbitration and it is not contrary to the peremptory rules, it is reasonable to assert that the consent will not be problematic.

\section{Legal Nature of Banking Operations and Processes}

\subsection{Legal Nature of Deposit Receiving by Banks}

Since all banking activities must be performed in the framework of free usury banking principles, banks can 
accept deposits in two main groups. First, Non-profit accounts including current interest-free accounts and interest-free savings accounts; second, profit accounts including short-term and long-term investment deposits. As mentioned, legal nature of the current interest-free accounts and savings is loan. Therefore, it contains all principles of loan. According to Article 648 of Civil Code, A Loan is a contract where by one of the two parties surrenders to the ownership of the other party a definite portion of his property, so that the other party may return to him what is equivalent thereto in respect of quantity, kind and description, and if that party declines to give back the equivalent, he gives the price of the same on the day of payment. The contracts in this regard are concluded based on Article 10 of the Civil Code and the principle is the consensual nature of them. It has no specific title in law and its conditions are determined according to the general principles of contracts and the principle of party autonomy (Katouzian, 2013). In investment deposits, the account owners entrust their money to the bank in accordance with contract law. Delegation is the relationship between depositor and the bank. Depositor gives a general delegation to the bank to share his fund along with other depositors in addition to the bank sources in profitable economic activities. Thus, bank has two legal relationships to the depositor. On the one hand, bank is his attorney in the employment of funds; on the other hand, it is his partner in the supply of sources. It is also the mediator between an investment depositor to other investment depositors. Given that bank is the attorney of the depositors, it can insure their deposits by paying premium from his own assets of the clients' money. In the same manner, it can take the responsibility of possible losses and return the deposit (Mosavian, 2014).

\subsection{Legal Status of Contracts of Granted Facilities}

Since all Iranian banks are obliged to observe the principles of free usury banking in their activities, resource allocation department uses two types of contracts: (1) Non-profit contracts including interest-free loans; (2) profit contracts. Profit contracts are divided into two types.

- Contracts with fixed return including installment sales, Slaf, buying liability, and Murabaha; they are called profit-transactional contracts. In this type of contracts, bank and client trade a property and the bank earns religious profit in its exchange. These contracts are certain, absolute, possessive in terms of nature; they also do not need supervision, and continuous control. The debtor and creditor relationship is established between bank and the facility receiver.

- Contracts with variable yields or partnership contracts such as civil partnership contracts and Muzaraba; they are called profit-partnership contracts. Muzaraba contract, civil partnership, legal partnership, Muzara'a, and Musaqat are examples in this regard. In this group, banks and customers begin a common economic activity to earn a profit. They share the earned profit with the ration having been determined in the contract in advance. The profit is expected profit; they also require continuous control (Mosavian, 2014).

\subsection{Legal Nature of Contracts Concluded by Electronic Banking Operations}

Electronic banking has been developed with the development of information technology and its application in banking industry in present situation of the world. For people's access to electronic banking, it is necessary to establish an electronic payment system to provide technological and legal infrastructures that facilitates transfer of value between the two parties (Nik Khah, 2011, p. 237). In the information system of electronic payments, customer makes data message; it contains a symbol of an event, information, or concept that is sent. For production of data message, he need electronic signature; it is any kind of organized sign or arranged with a logical pattern. It is used by system to identify the person who has signed the data message. Electronic payment system should receive data message and approve electronic signatures that is the entered password. In this way, the banking operation is performed; thus, electronic message exchange has a particular position because data message, which describes the service, must signifies the definite will of speaker indicating obligation to its provisions in the case of accepting the audience's response for accepting him. Obviously, the contract does not establish in case of non-acceptance by electronic payment system. In electronic transactions, data transfer and exchange over the Internet through electronic interfaces can be a valid way to announce the will of establishment by a person to create a legal effect. In fact, people select electronic instruments to create a legal effect among them.

\subsection{Legal Nature of Contracts Concluded by Private Sector Companies}

Privatization is one of the most important tools for governments to implement economic and social programs. In private sectors, employed person does not encounter the rigid and inflexible labor contracts and they take the advantages of labor laws and social security. Labor contracts for temporary period, contracts for performing certain work, and permanent work contracts are categories in this regard. In this respect, banks assign cleaning, driving, operators, and supporting computer systems through tender to human resources supply companies and 
technical companies of the private sector that are qualified by Administration of Labor and Social Security or Supreme Council for Informatics. They supply the work force based on the banks' requirements or they support computer systems. It is obvious that the employed persons in these companies have no employment relationship to banks. Contracts are adjusted among them according to Article 10 of Civil Code. In the conflict between labor and private enterprise, Administration of Labor and Social Security is responsible for solving the case; but the disputes between bank and a private sector is resolved usually negotiation and they try to minimize the future disagreements. In the case of any disagreement, bank expert will interpret the case. However, the company has the right to refer to judicial branch.

\section{Conclusion}

As customers prefer to keep their information secret and the speed in addressing a situation for keeping the value of money is very important for them, they like to solve their problems with banks without any referring to judicial branch. Moreover, banks do not like to resolve disputes through arbitration because they are worry about heavy sentences by non-competent judges. Hence, they try more to use alternative ways, especially referral to experts and negotiators. In the contracts of deposit receiving granted facilities, this subject has been expressed by some specific terms; the idea of bank expert is ruling in some cases. Due to the interest in continued cooperation in the future, negotiation and referral to expert for solving disputes are the ways used in the contracts between a bank and companies. For maintaining data security, referring to bank expert is used in electronic banking. When the customer is responsible for banking operations, referring to arbitration is irrelevant. With respect to Articles two and three of Commercial Code, the main commercial transactions include banking and insurance and operations are recognized as commercial in so far as one or both of the contracting parties are merchants, when all business transactions between merchants, tradesmen, money-exchangers and banks, when all business transactions between a merchant and a non-merchant for his commercial requirements, when all business transactions undertaken by the staff, employees or apprentices of merchants on behalf of their employers, and when all transactions of commercial companies. Thus, any disagreement resulting from the relations between people and banks can be subject to commercial arbitration because banks are regarded as a merchant by law. If the customer is a merchant, the established relation between them is regarded as a commercial transaction. If the customer is not merchant, their relation is regarded as sub sequential commercial transaction because one party (bank) is merchant.

In addition, scholars interested in arbitration can use following subjects in future studies:

- Position of arbitration in solving disputes of banks with bankrupted customers

- Ability to refer disputes of banks with their officials and contractors to arbitration

- Ability to refer disputes of customers with employees of banks to arbitration

- Position of arbitration in solving disputes of banks and organizations and public institutions

\section{References}

Bahmani, M., \& Moradi, F. (2015). Parties to arbitration clause in a contract group. International Law Journal, 52(2), 35-60.

Dashti, M., \& Karimi, A. (2013). Comparative study of arbitration, formal, and consensual agreements. Journal of Comparative Studies on Law, 4(1), 9-115.

Eskini, R. (2009). Commercial Law for Commercial Companies (Vol. II, 11th ed.). Tehran: SAMT Publications.

Hasani, H. (2012). Cooperation law and commercial law (2nd ed.). Tehran: Mizan Legal Foundation.

Jafari Langroodi, M. J. (1991). Law Terminology (5th ed.). Tehran: Treasure of Knowledge Library.

Karimi, A., \& Partou, H. (2012). Accepting arbitration in claims relating to public and state property. Journal of Research on Law and Politics, 14(36), 157-184.

Karimi, A., \& Partou, H. (2013). Domestic arbitration law (2nd ed.). Tehran: Justice.

Katouzian, N. (2013). General principles of contracts (Vol. 1, 11th ed.). Tehran: Publishing Joint Stock Company.

Mosavian, S. (2014). An Introduction to Free Usury Banking in Iran (1st ed.). Tehran: Cultural Institute of Contemporary Knowledge and Thought (FAM).

Muhammadi, A. (2009). Customer orientation in honoring customers (7th ed.). Tehran: Resa Institute of Cultural Services. 
Mujtahedi, M. (2012). Characteristics of internal, external, and international arbitration as well as the determinant role of each type. Journal of Bar Association, I8(28), 69-82.

Nik Khah, B. (2011). Managing the quality of electronic banking services (1st ed.). Tabriz: Akhtar Publication.

Pasha Bonyad, M. (2014). Arbitration (2nd ed.). Tehran: Negahe Bayeneh Publication.

Sarvari, M. (2011). Position of arbitration in the law on Pre-sale of the building. Monthly Journal of judgment, $70(2), 6-8$.

Shiravi, A. (2013). International Commercial Arbitration (2nd ed.). Tehran: SAMT Publications.

\section{Copyrights}

Copyright for this article is retained by the author(s), with first publication rights granted to the journal.

This is an open-access article distributed under the terms and conditions of the Creative Commons Attribution license (http://creativecommons.org/licenses/by/4.0/). 